\title{
Cattle and water buffalo densities wading into small village reservoirs of Sri Lanka impact on yields on the culture-based fisheries thereof
}

\author{
Asanka D. Jayasinghe ${ }^{1 * \dagger}+$ J. Arachchige Athula ${ }^{2} \ddagger$, Sena S. De Silva ${ }^{3}$ and Upali S. Amarasinghe ${ }^{1}$ \\ ${ }^{1}$ Department of Zoology, University of Kelaniya, Kelaniya 11600, Sri Lanka \\ ${ }^{2}$ National Aquaculture Development Authority, No. 41/1, New Parliament Road, Pelawatte, \\ Battaramulla 10120, Sri Lanka \\ ${ }^{3}$ School of Life and Environmental Sciences, Deakin University, Warrnambool, Victoria 3280, \\ Australia
}

$\uparrow$ Present address: Department of Limnology and Water Technology, Faculty of Fisheries and Marine Science \& Technology, University of Ruhuna, Wellamadama, Matara 81000, Sri Lanka

+ Present address: Department of Animal Science, Faculty of Animal Science and Export Agriculture, Uva Wellassa University, Badulla 90000, Sri Lanka

* Correspondence (asanka@ fish.ruh.ac.lk)

iD https://orcid.org/0000-0002-7528-7718

\begin{abstract}
This study investigated whether allochthonous inputs generated by cattle and water buffaloes grazing in the catchment or wading in the water in small village reservoirs of Sri Lanka can make a significant effect on yields from culture-based fisheries of those reservoirs. The analysis is based on limnological data of 37 randomly selected reservoirs. As culture-based fish yield data were available over the 2002 - 2003 period only for 23 reservoirs, fish yield data from seven more reservoirs were gleaned for the present analysis. Cattle and water buffalo densities (BD) in 37 reservoirs where limnological data were available, were found to be significantly correlated to the biological productivity-related parameters such as chlorophyll-a content. Culture-based fish yield in the 30 reservoirs varied from 54.6 to $1800.8 \mathrm{~kg} \mathrm{ha}^{-1}$ and BD associated with the reservoirs studied varied from 0.90 number ha ${ }^{-1}$ to 216.25 numbers ha ${ }^{-1}$. Fish yield (FY) was significantly correlated with BD the relationship being, FY $=4.758 \mathrm{BD}$ $+242.740\left(R^{2}=0.345 ; \mathrm{p}<0.001\right)$. The importance of taking into consideration factors such as grazing cattle and buffalo density in preparing management strategies for culture-based fisheries in small village reservoirs is discussed.
\end{abstract}

Keywords: allochthonous nutrient inputs; exotic carps; inland fisheries; irrigation reservoirs; stocking-and-recapture fisheries

\section{INTRODUCTION}

Animal faeces are a conventional type of fertilizer commonly used in aquaculture systems in many developing tropical countries. Addition of such organic fertilizer is done manually or through a self-nourishing systems for example as in integrated farming; fish-cum-poultry farming. Cattle manure (cow dung) can be manually added to pond water considering the nature of cultured organism, water quality and soil characteristics of that area (Bardach et al. 1972). In pond fish culture cow dung is often used in combination with or without poultry manure and/ or inorganic inputs.
For rearing Indian or Chinese carps the conventional manure dosage for pond fertilization may vary between $10-50 \mathrm{t} \mathrm{ha}^{-1} \mathrm{yr}^{-1}(\mathrm{Li}$ and $\mathrm{Xu}$ 1995; Garg and Bhatnagar 2000; Das et al. 2005), and often unattainable due to scarcity of manure. In culture-based fisheries, a natural or a man-made water body often relatively far larger than a fish pond makes manual fertilization impractical. Nevertheless, if it is a non-perennial water body, which is smaller in size and if there is a higher density of cattle (Bos taurus L.) and water buffaloes (Bubalus bubalis (L.)) grazing within the catchment and wading into the water body the scenario would appear as an integrated farm setup. 
For example, an experimental introduction of grazers for a $10 \mathrm{hr}$ period to a small catchment in New Zealand was reported to increase particulate phosphorus in the water 100 times as opposed to the pre-grazing status (Sharpley and Syers 1979). Sharpley and Syers (1979) also observed that the disturbance of sediments by cattle movements and deposition of excreta within water enhanced the situation. Nutrient enrichment is reported to take place in a reservoir complex in Sri Lanka, which is a wetland of international importance (i.e., a Ramsar site) due to accumulation of faecal matter of migratory and resident birds, the phenomenon termed as 'guanotrophication' (Jayakody et al. 2012) and 'ornithological eutrophication' (Gunaratne et al. 2015).

Cattle and/or water buffalo are an integral part in Asian agrarian civilizations for thousands of years. The value of water buffalo is not only for milk, meat, hides and draft power for agricultural operations but sociologically as property, possession and a readily available currency converter when in need for farmer communities (Nanda and Nakao 2003). There are more than 12000 non-perennial reservoirs (not exceeding 50 ha at full supply level) scattered mainly in the dry zone of Sri Lanka (Anon. 2000) while there are estimated 3,108,620 water buffaloes and 1,068,044 cattle (2016 census) predominantly in the same agricultural areas (FAOSTAT 2017). Throughout the history, country was dominated by an agrarian society based on a "one tank - one village" ecological pattern (Siriweera 1994). Each village consists of a small irrigation reservoir, paddy fields irrigated from that reservoir and the dwellings of the owners of those paddy lands. Every cattle and water buffalo in the village graze in the reservoir catchment and at least once a day wade in the shallow water. Therefore, the reservoirs are subjected to direct or indirect inputs of allochthonous nutrients via cattle and water buffalo urine and faecal matter. As these small village reservoirs are suitable for the development of culture-based fisheries (Mendis 1965, 1977; De Silva 1988; Amarasinghe 1998) inducedproductivity through cattle and buffalo depositions are likely to impact positively on fish yields. The present analysis is based on data collected for a major reservoir fisheries development project attempting to quantify the effect of grazing cattle and water buffalo density (BD) on culture-based fish yields, and compliments the previous findings on stocking density and limnological features impacting on culture-based fisheries yield in small village reservoirs of Sri Lanka (Jayasinghe et al. 2005a, 2005b, 2006; Wijenayake et al. 2005).

\section{MATERIALS AND METHODS}

This investigation was concurrent to a major research project on the enhancement of culturebased fisheries in small village reservoirs of Sri Lanka, and the relevant methodologies have been reported earlier (Jayasinghe et al. 2005a, 2005b, 2006; Wijenayake et al. 2005). In the present analysis, data were used from 48 small village reservoirs in five administrative districts, which were randomly selected for stocking fish fingerlings. Data on the number of cattle and water buffalo associated with each reservoir were retrieved from resource profiles of village authorities and Divisional Secretariat Division offices. Cattle and water buffalo densities (BD) were calculated by dividing their number by reservoir area at full supply level. Of the selected reservoirs, only 30 could be successfully utilized for a fish culture cycle (of $8-10$ months) during 2002 - 2003 period, and the data of fish yields in the rest of the reservoirs were not reliable due to false reporting and poaching (Jayasinghe et al. 2005a, 2005b, 2006), and therefore were discarded. The reservoirs were stocked with fingerlings of exotic species rohu (Labeo rohita Hamilton), catla (Catla catla Hamilton), common carp (Cyprinus carpio L.), bighead carp (Aristichthys nobilis Richardson), mrigal (Cirrhinus mrigala Hamilton), the GIFT strain of Nile tilapia (Oreochromis niloticus L.) and the indigenous species, giant freshwater prawn (Macrobrachium rosenbergii De Man). Stocking densities ranged from 218 to 4372 fingerlings $\mathrm{ha}^{-1}$. When the water level of reservoirs was $0.5-1.0 \mathrm{~m}$ along with the dry season, all fishes surviving were caught using a $5 \mathrm{~cm}$ mesh 62 $\mathrm{m} \times 8.5 \mathrm{~m}$ seine net and the total fish yield was estimated for each reservoir (Table 3).

Previous investigations on limnological parameters of small village reservoirs have revealed that parameters such as Secchi disc depth, total phosphorous, chlorophyll-a, inorganic and organic turbidity determine the trophic 


\section{A.D. Jayasinghe et al.}

heterogeneity of those reservoirs (Jayasinghe et al. 2005b). In this analysis, we attempted to find out possible relationships of these limnological parameters with cattle and water buffalo densities. However, in seven reservoirs in the Hambantota district, water quality parameters could not be determined due to various practical difficulties encountered such as non-availability of transport facilities.

In the present analysis, the potential impacts of cattle and water buffalo separately on the nutrient enrichment in reservoirs were not differentiated, due to logistical difficulties. As such the combined density of cattle and water buffalo was taken as the index of nutrient enrichment even though nitrogen, phosphorous, potassium and calcium contents of cattle and water buffalo excreta (dung and urine) are known to be different (Kolay 2007), and this is a potential area for further investigation on relative contribution to productivity from cattle as opposed to water buffaloes.

Inter-relationships between biological productivity-related limnological parameters were determined. The relationships of cattle and water buffalo densities (BD) with these biological productivity-related limnological parameters were also determined. Finally, for the 30 reservoirs with a successful culture-based fisheries harvest, BD was related to the culture-based fish yield.

\section{RESULTS}

Extents of reservoirs used in the present analysis varied from 2.7 ha of Burutha wewa in Anuradhapura district to 46.0 ha of Nimalawa wewa in Hambantota district. Cattle and water buffalo densities associated with the reservoirs studied varied from 0.90 numbers $\mathrm{ha}^{-1}$ in Meegahawewa in Anuradhapura district to 216.25 numbers $\mathrm{ha}^{-1}$ in Swodagama wewa in the
Hambantota district (Table 1). As mentioned above limnological data were available only from 37 reservoirs and culture-based fisheries yields were from 30 reservoirs (Table 1). Culture-based fish yield in the fish culture cycle during $2002-2003$ period in the 30 reservoirs ranged from $54.6 \mathrm{~kg}^{-}$ ${ }^{1}$ to $188.8 \mathrm{~kg} \mathrm{ha}^{-1}$.

Secchi disc depth (SDD), which is an important parameter indicating underwater light attenuation, was found to be influenced negative log-linearly by both organic turbidity (Figure 1A) and inorganic turbidity (Figure 1B). The negative logarithmic relationship between SDD and chlorophyll-a content (Figure 1C) is also evident indicating that phytoplankton biomass was drastically low in reservoirs with high light penetration. Secchi disc depth had a negative loglinear relationship with the cattle and water buffalo density (Figure 2A). The positive log-linear relationships of cattle and water buffalo density with organic turbidity (Figure 2B) and inorganic turbidity (Figure 2C) indicate that high densities of grazing cattle and buffaloes could be a reason for declined water transparency. A positive linear relationship between cattle and water buffalo density and chlorophyll-a content is evident from the present analysis (Figure 2D) showing that grazing cattle and water buffaloes had noticeable positive effect on the biological productivity of the reservoirs. All the regression relationships presented in Figures 1 and 2 were significant at least at 0.05 probability level (Table 2). Culturebased fisheries yield ( $\mathrm{FY}$ in $\mathrm{kg} \mathrm{ha}^{-1} \mathrm{yr}^{-1}$ ) in the 30 reservoirs showed a significant correlation to cattle and buffalo density (BD in numbers $\mathrm{ha}^{-1}$ ), the relationship being, $\mathrm{FY}=4.758 \mathrm{BD}+242.740\left(\mathrm{R}^{2}=\right.$ $0.345 ; \mathrm{p}<0.001$; Figure 3). 
Table 1. Major biological productivity-related limnological data, cattle and water buffalo densities (BD) and culturebased fish yield in small village reservoirs studied. FSL - full supply level; SDD - Secchi disc depth; OT - organic turbidity; IT - inorganic turbidity; TP - total phosphorous; Chl-a - chlorophyll-a content; nd - no data. (Source of limnological data: Jayasinghe et al. 2005b; Fisheries data: Jayasinghe et al. 2005b and present study)

\begin{tabular}{|c|c|c|c|c|c|c|c|c|}
\hline District/Reservoir & $\begin{array}{l}\text { Extent at } \\
\text { FSL (ha) }\end{array}$ & $\begin{array}{l}\text { SDD } \\
(\mathrm{cm})\end{array}$ & $\begin{array}{r}\text { OT } \\
\left(\mathrm{mg} \mathrm{L}^{-1}\right) \\
\end{array}$ & $\begin{array}{r}\text { IT } \\
\left(\mathrm{mg} \mathrm{L}^{-1}\right) \\
\end{array}$ & $\begin{array}{r}\mathrm{TP} \\
\left(\mathrm{mg} \mathrm{L}^{-1}\right) \\
\end{array}$ & $\begin{array}{r}\text { Chl-a } \\
\left(\mathrm{mg} \mathrm{m}^{-3}\right) \\
\end{array}$ & $\begin{array}{r}\text { BD } \\
\left(\text { Nos ha }^{-1}\right) \\
\end{array}$ & $\begin{array}{r}\text { Fish yield } \\
\left(\mathrm{kg} \mathrm{ha}^{-1}\right) \\
\end{array}$ \\
\hline \multicolumn{9}{|l|}{ Anuradhapura } \\
\hline Bulankulama & 10.4 & 69.6 & 9.26 & 17.63 & 0.20 & 6.95 & 0.96 & 352.5 \\
\hline Burutha wewa & 2.7 & 31.3 & 15.04 & 38.69 & 0.33 & 40.27 & 182.22 & nd \\
\hline Gambirigas wewa & 16.6 & 69.9 & 9.59 & 15.86 & 0.48 & 5.34 & 10.54 & 127.1 \\
\hline Hinguruvelpitiya & 7.8 & 101.1 & 7.57 & 8.29 & 0.49 & 1.88 & 12.85 & nd \\
\hline Karambegama & 9.3 & 77.9 & 14.81 & 15.33 & 0.20 & 1.37 & 1.07 & nd \\
\hline Katugampalagama & 16.7 & 41.9 & 17.42 & 41.77 & 0.27 & 7.92 & 29.98 & 242.9 \\
\hline Lolugas wewa & 11.9 & 62.4 & 15.87 & 35.86 & 0.21 & 12.32 & 8.40 & nd \\
\hline Maha wewa & 8.4 & 38.6 & 40.76 & 112.00 & 0.25 & 19.16 & 23.93 & nd \\
\hline Meegaha wewa & 11.1 & 49.3 & 13.73 & 104.59 & 0.44 & 4.57 & 0.90 & nd \\
\hline Meegassegama & 29.0 & 66.9 & 16.33 & 22.81 & 0.16 & 6.51 & 5.18 & nd \\
\hline Pahalasandalamkulama & 21.3 & 33.8 & 27.63 & 91.18 & 0.28 & 16.63 & 23.51 & 194.5 \\
\hline \multicolumn{9}{|l|}{ Kurunegala } \\
\hline Kumbalporuwa & 9.5 & 136.4 & 3.05 & 2.32 & 0.13 & 1.92 & 8.41 & nd \\
\hline Kekunawa & 10.0 & 74.4 & 6.78 & 9.48 & 0.23 & 16.05 & 5.02 & nd \\
\hline Ihalamaradankadawala & 19.2 & 132.2 & 4.08 & 10.40 & 0.16 & 1.57 & 16.19 & nd \\
\hline Pahala wewa & 8.5 & 42.7 & 22.65 & 57.70 & 0.39 & 30.23 & 23.49 & nd \\
\hline Hindagaha wewa & 2.9 & 55.4 & 11.29 & 34.33 & 0.19 & 3.10 & 43.66 & nd \\
\hline Withikuliya wewa & 6.9 & 85.2 & 5.30 & 10.97 & 0.17 & 2.80 & 3.60 & nd \\
\hline Wavullewa wewa & 20.6 & 108.6 & 1.50 & 7.58 & 0.21 & 1.03 & 24.23 & 120.4 \\
\hline Matulu wawa & 28.9 & 72.0 & 1.39 & 11.61 & 0.14 & 12.48 & 3.47 & 56.7 \\
\hline \multicolumn{9}{|l|}{ Hambantota } \\
\hline Bolhinda & 11.6 & 18.4 & 28.95 & 88.14 & 0.44 & 13.46 & 129.65 & nd \\
\hline Gonnoruwa & 22.4 & 16.4 & 70.91 & 446.05 & 0.58 & 9.89 & 22.33 & 54.6 \\
\hline Kudaindi wewa & 13.4 & 13.6 & 26.12 & 93.22 & 0.22 & 4.21 & 37.30 & 377.1 \\
\hline Udana wewa & 4.9 & 36.2 & 6.93 & 28.62 & 0.52 & 3.45 & 91.65 & nd \\
\hline Lunuveraniya & 10.8 & 15.8 & 28.79 & 140.46 & 0.25 & 18.10 & 92.98 & 710.4 \\
\hline Medagankadavara & 16.7 & 21.4 & 16.07 & 68.33 & 0.47 & 29.14 & 89.61 & 72.4 \\
\hline Palujadura & 4.9 & 45.5 & 9.60 & 46.45 & 0.21 & 7.45 & 51.49 & 275.9 \\
\hline Svodagama & 3.2 & 10.6 & 35.52 & 122.81 & 0.49 & 86.60 & 216.25 & 1800.8 \\
\hline Weli wewa & 5.7 & 27.0 & 28.11 & 48.60 & 0.37 & 29.71 & 10.57 & 372.7 \\
\hline Wawegama & 18.9 & 7.5 & 165.46 & 258.90 & 0.47 & 7.96 & 61.00 & 181.9 \\
\hline Andalla wewa & 25.1 & nd & nd & nd & $\mathrm{Nd}$ & nd & 20.93 & 280.2 \\
\hline Katupila wewa & 14.6 & nd & nd & nd & $\mathrm{Nd}$ & nd & 64.98 & 522.4 \\
\hline Nimalawa wewa & 46.0 & nd & nd & nd & $\mathrm{Nd}$ & nd & 16.38 & 96.9 \\
\hline Palugas wewa & 18.8 & nd & nd & nd & $\mathrm{Nd}$ & nd & 23.94 & 321.5 \\
\hline Orukengala wewa & 6.3 & nd & nd & nd & $\mathrm{Nd}$ & nd & 143.77 & 853.9 \\
\hline
\end{tabular}


A.D. Jayasinghe et al.

\begin{tabular}{lrrrrrrrr} 
Angunukola wewa & 8.4 & nd & nd & nd & Nd & nd & 149.52 & 878.0 \\
\hline Neralugas wewa & 16.7 & nd & nd & nd & Nd & nd & 10.47 & 333.9 \\
Hambuwe wewa & 10.5 & nd & nd & nd & Nd & nd & 86.21 & 731.1 \\
Unathu wewa & 12.5 & nd & nd & nd & Nd & nd & 79.74 & 508.1 \\
Pelessa wewa & 29.3 & nd & nd & nd & Nd & nd & 5.13 & 141.7 \\
Mahapelessa wewa & 18.8 & nd & nd & nd & Nd & nd & 5.32 & 235.0 \\
Moneragala & & & & & & & & \\
Dozerwewa & 13.6 & 21.1 & 25.43 & 107.74 & 0.40 & 38.56 & 14.72 & 1513.9 \\
Bodhagama wewa & 13.4 & 22.1 & 17.29 & 128.86 & 0.36 & 7.08 & 7.44 & 623.4 \\
Galwale wewa & 15.7 & 38.5 & 18.07 & 85.83 & 0.20 & 5.82 & 44.48 & 247.9 \\
Meegas wewa & 21.0 & 19.3 & 15.35 & 106.40 & 0.32 & 13.48 & 9.53 & 715.6 \\
Batalaara wewa & 11.0 & 66.0 & 9.72 & 12.77 & 0.11 & 13.17 & 2.72 & nd \\
Walaskema wewa & 28.1 & 15.2 & 20.90 & 97.03 & 0.26 & 10.78 & 71.09 & nd \\
Ratnapura & & & & & & & & \\
Mahagalara & 8.9 & 81.5 & 3.50 & 12.00 & 0.16 & 13.89 & 17.51 & 877.1 \\
Panahaduwa & 30.5 & 27.8 & 30.67 & 128.34 & 0.29 & 30.21 & 39.37 & nd \\
\hline
\end{tabular}

(A)
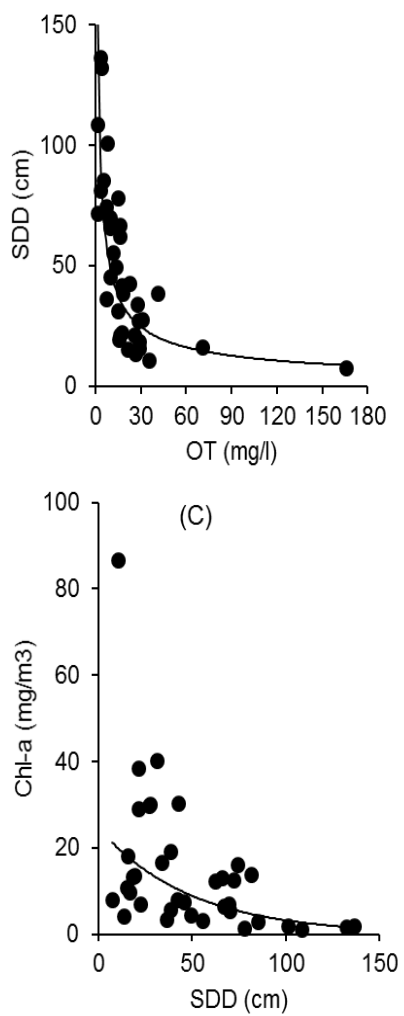

(B)

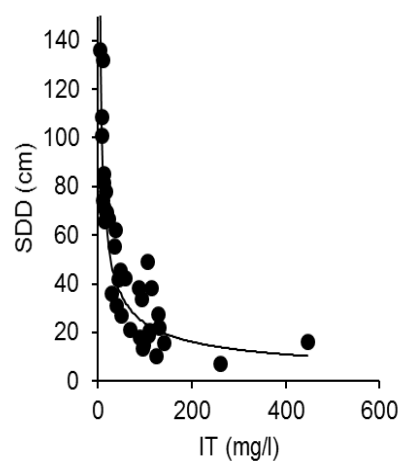

Figure 1. Interrelationships of biological productivity-related limnological parameters in 37 small village reservoirs studied (Data from Jayasinghe et al. 2005). SDD - Secchi disc depth; OT - organic turbidity; IT - inorganic turbidity; Chl-a - chlorophyll-a content. 

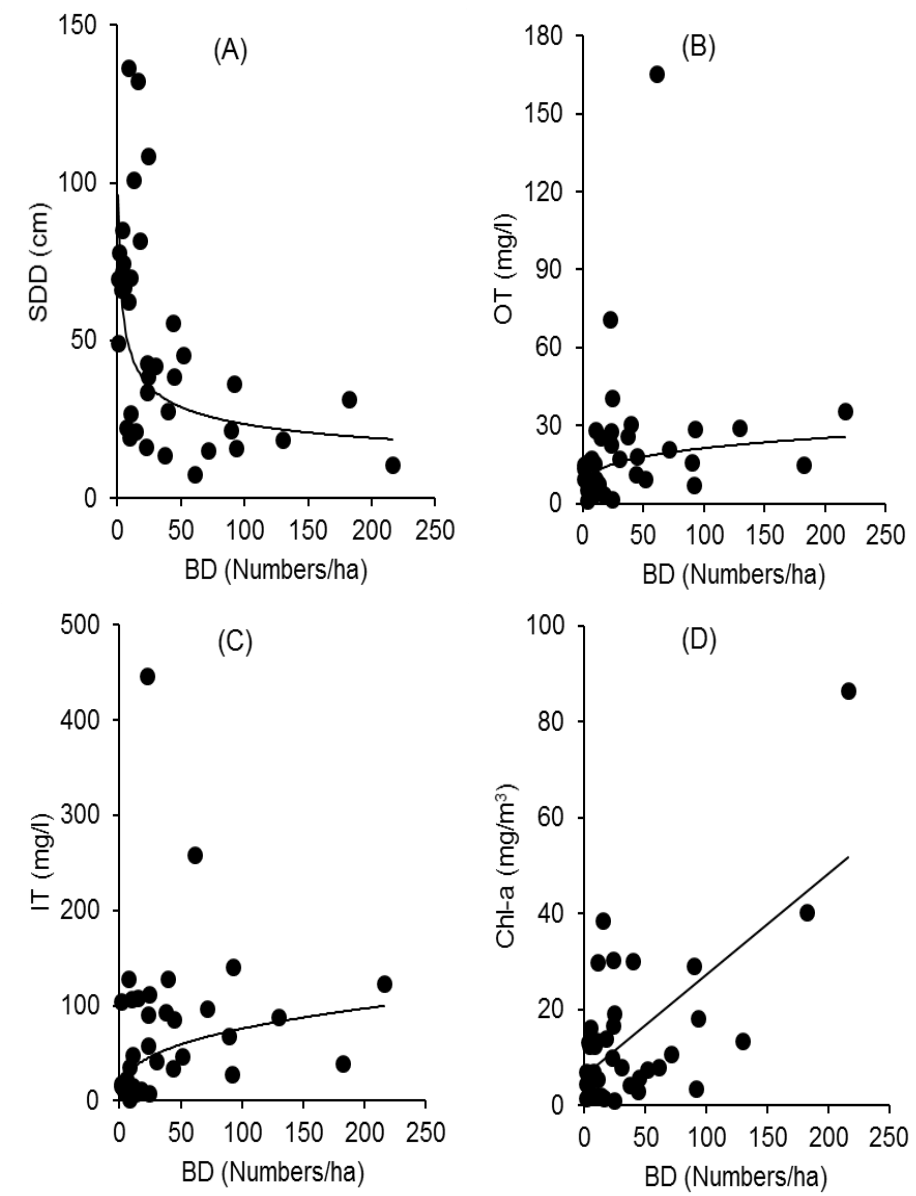

Figure 2. Relationships of cattle and water buffalo density (BD) with biological productivity-related limnological parameters in 37 small village reservoirs studied. SDD - Secchi disk depth; OT - organic turbidity; IT - inorganic turbidity; Chl-a - chlorophyll-a content.

Table 2. Regression relationships shown in Figures 1 and 2. $\mathrm{df}-$ degrees of freedom; $r=$ correlation coefficient; $\mathrm{p}$ - probability level.

\begin{tabular}{lllll}
\hline Relationship & Df & $\mathrm{R}$ & $\mathrm{p}$ & Figure No. \\
\hline $\mathrm{SDD}=196.680 \mathrm{OT}^{-0.611}$ & 35 & 0.804 & $<0.001$ & $1 \mathrm{~A}$ \\
$\mathrm{SDD}=315.450 \mathrm{IT}^{-0.561}$ & 35 & 0.886 & $<0.001$ & $1 \mathrm{~B}$ \\
$\mathrm{Chl}-\mathrm{a}=24.707 \mathrm{e}^{-0.020} \mathrm{SDD}$ & 35 & 0.659 & $<0.001$ & $1 \mathrm{C}$ \\
$\mathrm{SDD}=92.988 \mathrm{BD}^{-0.299}$ & 35 & 0.573 & $<0.001$ & $2 \mathrm{~A}$ \\
$\mathrm{OT}=6.846 \mathrm{BD}^{0.246}$ & 35 & 0.359 & $<0.05$ & $2 \mathrm{~B}$ \\
$\mathrm{IT}=14.657 \mathrm{BD}^{0.357}$ & 35 & 0.433 & $<0.01$ & $2 \mathrm{C}$ \\
$\mathrm{Chl}-\mathrm{a}=0.210 \mathrm{BD}+6.299$ & 35 & 0.649 & $<0.001$ & $2 \mathrm{D}$ \\
\hline
\end{tabular}


A.D. Jayasinghe et al.

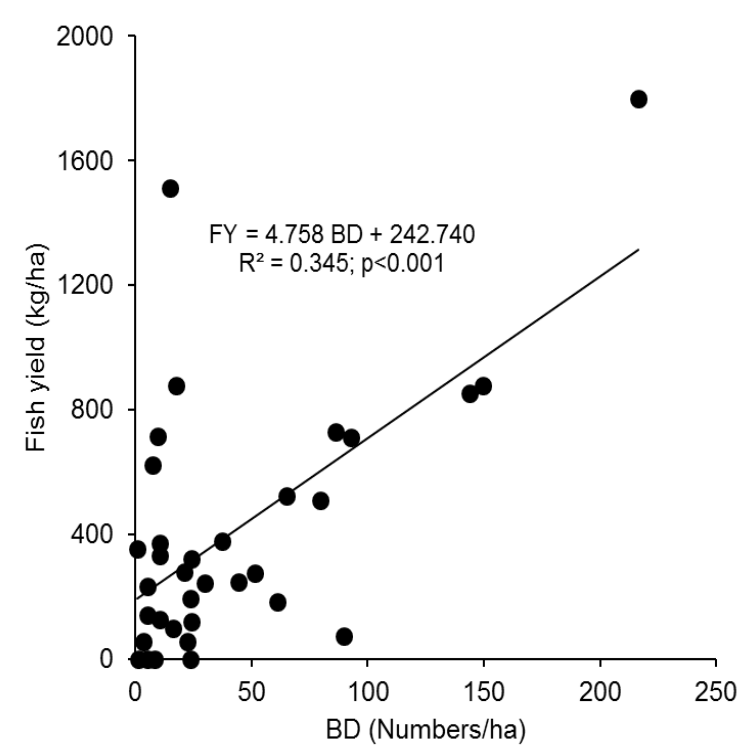

Figure 3. Relationship between cattle and water buffalo density (BD) and culture-based fish yield in 30 village reservoirs.

\section{DISCUSSION}

Cattle and water buffalo rearing is a common activity in most rural areas in Asia. These livestock with individual identification marks, are often permitted to graze and water in common pool resources such as small village reservoirs and the corresponding catchments, freely, and is herded in the evenings by their owners. This is a common life style in rural Sri Lanka, particularly in the dry zone areas where each village is bestowed with a small irrigation reservoir. The current study has demonstrated that the grazing cattle and water buffalo density impacts the fish yield in the corresponding reservoir, as expected, but quantitatively for the first time.

Livestock grazing within the catchments contribute a considerable amount of nitrogen and phosphorus through their urine and faecal matter (DEFRA 2002; English Nature 2003; Jennings et al. 2003). Though the amount of phosphorus is low in cattle urine (Braithwaite 1976), a considerable amount is heaped on the soil via faeces (Nash and Halliwell 1999, 2000; Bravo et al. 2003). Furthermore, nutrient release rate from dung is normally higher than that released from submerged vegetation although there are slight differences due to animal species that produce it (McLachlan 1971).
Nutrients are transported via surface runoff, subsurface flow and leaching to ground water, which are spatially and temporally dynamic pathways (Jennings et al. 2003). Draw down areas of small village reservoirs are open to the growth of grass or shrubs and remain dry for most of the time in the year. Also, these areas are mottled with piles of dung. During the dry periods, residues of faecal wastes may accumulate in the soil (Jennings et al. 2003). With low frequency/high intensity rainfall, great losses of nutrients from soil to nearby water bodies can occur. Subsequently the nutrient load in water is expressed by the high level of chlorophyll content. Present study shows strong relationships between key limnological parameters responsible for trophic differences of small village reservoirs and cattle/ buffalo density associated with those reservoirs.

Amount of allochthonous inputs into a water body is largely determined by the extent of the land-water interface. Regardless of the cattle and buffalo density, dendritic margin of a reservoir increases the allochthonous nutrients, and thus productivity. The significance of shoreline: area ratio as a good predictor of culture-based fish yield in small village reservoirs of Sri Lanka was shown by Jayasinghe et al. (2006). Higher values of this morphometric parameter are effective in resulting an increased culture-based fish yield. Also, from the present analysis it is evident that fish yield can be optimized if, simultaneously, there is a higher cattle and water buffalo density associated with the reservoir and the fishery is well managed by keeping the stocking density at an optimum level, as shown by Wijenayake et al. (2005).

Due to easy access to databases on cattle and water buffalo density in villages, as given in resource profiles of divisional secretariats, for fisheries management purposes, it is practicable to use data on cattle and water buffalo density rather than measuring chlorophyll-a content of the water for which technical skills and lab facilities are necessary. For years to come, the link between cattle and water buffaloes and agrarian communities will be persistent in spite of the technological innovations. Among numerous helps of these animals to mankind, indirect fertilizing of the culture facility in culture-based fisheries would be another important one with its wise use not only in Sri Lanka but also in most agrarian communities in Asia. 


\section{Acknowledgements}

The authors wish to acknowledge financial support from the Australian Centre for International Agricultural Research (ACIAR Project No. FIS/2001/030).

\section{REFERENCES}

Amarasinghe, U.S. 1998. How effective are the stocking strategies for the management of reservoir fisheries in Sri Lanka? pp. 422-436. In: I.G. Cowx (ed.) Stocking and Introductions of Fish. Fishing News Books. Blackwell Science Ltd., Oxford.

Anon. 2000. Data book for village irrigation schemes of Sri Lanka (23 volumes). Department of Agrarian Services, Colombo.

Bardach, J.E., J.H. Ryther and W.O. McLarney 1972. Aquaculture: The Farming and Husbandry of Freshwater and Marine Organisms. Wiley-Interscience, New York. 868 pp.

Braithwaite, G.D. 1976. Calcium and phosphorus metabolism in ruminants with special reference to parturient paresis. Journal of Dairy Research 43: 501-520.

doi:https://doi.org/10.1017/S002202990001609 5

Brämick, U. and R. Lemcke 2003. Regional application of a fish yield estimation procedure to lakes in north-east Germany. Limnologica 33: 205-213. doi:https://doi.org/10.1016/S00759511(03)80014-2

Bravo, D., D. Sauvant, C. Bogaert and F. Meschy 2003. III. Quantitative aspects of phosphorus excretion in ruminants. Reproduction Nutrition Development 43: 285-300.

doi: 10.1051/rnd:2003021

Das, P.C., S. Ayyappan and J. Jena 2005. Comparative changes in water quality and role of pond soil after application of different levels of organic and inorganic inputs. Aquaculture Research 36: 785-798. doi: 10.1111/j.13652109.2005.01288.x

De Silva, S.S. 1988. Reservoirs of Sri Lanka and Their Fisheries. FAO Fisheries Technical Paper No. 298, FAO, Rome. 128 pp.

DEFRA 2002. Agriculture and Water: A Diffuse Pollution Review. The Government's Strategic
Review of Diffuse Water Pollution from Agriculture in England. Department for Environment, Food and Rural Affaires, United Kingdom. 15 pp.

English Nature 2003. Prioritizing designated wildlife sites at risk from diffuse agricultural pollution. English Nature Research Reports no. 551. English Nature, Peterborough. 212 pp.

FAOSTAT (2017). http://www.fao.org/faostat/en/ \#data (last visited 16/12/2017).

Garg S.K. \& Bhatnagar A. (2000). Effect of fertilization frequency on pond productivity and fish biomass in still water ponds stocked with Cirrhinus mrigala (Ham.). Aquaculture Research 31: 409-414. doi: 10.1046/j.13652109.2000.00422.x

Gunaratne, A.M., S. Jayakody and U.S. Amarasinghe 2015. "Ornithological eutrophication" as a source of allochthonus nutrient enrichment in Anavilundawa reservoir, Sri Lanka. International Review of Hydrobiology 100: 151-157.

doi: 10.1002/iroh.201501804

Jayakody, S., U.S. Amarasinghe and A.M. Gunaratne 2012. Guanotrophication in shallow reservoirs of Sri Lanka. SIL NEWS, The Newsletter of the Society of International Limnologists 61: 17-19.

Jayasinghe, U.A.D., U.S. Amarasinghe and S.S. De Silva 2005a. Trophic classification of nonperennial reservoirs utilized for the development of culture-based fisheries, Sri Lanka. International Review of Hydrobiology 90: 209-222. doi: 10.1002/iroh.200410753

Jayasinghe, U.A.D., U.S. Amarasinghe and S.S. De Silva 2005b. Limnology and culture-based fisheries in non-perennial reservoirs of Sri Lanka. Lakes and Reservoirs: Research and Management 10: 157-166. doi: 10.1111/j.1440-1770.2005.00271.x

Jayasinghe, U.A.D., U.S. Amarasinghe and S.S. De Silva 2006. Culture-based fisheries in nonperennial reservoirs of Sri Lanka: Influence of reservoir morphometry and stocking density on yield. Fisheries Management and Ecology 13: 157-164. doi: 10.1111/j.1365-2400.2006.00488.x 
A.D. Jayasinghe et al.

Jennings, E., P. Mills, P. Jordan, J. Jensen, M. Wijenayake, W.M.H.K., U.A.D. Jayasinghe, U.S. Sondergaard, A. Barr et al. 2003. Amarasinghe, J.A. Athula, K.B.C. Pushpalatha Eutrophication from agricultural sources: and S.S. De Silva 2005. Culture-based fisheries Seasonal patterns and effects of phosphorus. 2000-LS-2.1.7.-M2, Final report. Wexford, Ireland: Environmental Protection Agency, 61 pp.

Kolay, A.K. 2007. Manures and fertilizers. Atlantic Publishers and Distributers, New Delhi. 179 p.

Li, S. and S. Xu 1995. Culture and capture of fish in Chinese reservoirs. Southbound, Penang and International Development Research Centre, Ottawa. 128 pp.

McLachlan, S.M. 1971. The rate of nutrient release from grass and dung following emersion in lake water. Hydrobiologia 37: 521-530.

doi: https://doi.org/10.1007/BF00018817

Mendis, A.S. 1965. A preliminary survey of 21 Ceylon lakes, 2: Limnology and fish production potential. Bulletin of Fisheries Research Station, Ceylon 16: 7-16.

Mendis, A.S. 1977. The role of man-made lakes in the development of fisheries in Sri Lanka. Proceedings of Indo-Pacific Fisheries Council 17(3): 245-254.

Nanda, A.S. and T. Nakao 2003. Role of buffalo in the socioeconomic development of rural Asia: Current status and future prospectus. Animal Science Journal 74: 443-455. doi: 10.1046/j.1344-3941.2003.00138.x

Nash, D. and D. Halliwell 1999. Fertilizers and phosphorus loss from productive grazing systems. Australian Journal of Soil Research 37: 403-429. doi: https://doi.org/10.1071/S98087

Nash, D. and D. Halliwell 2000. Tracing phosphorus transferred from grazing land to water. Water Research 34: 1975-1985.

doi: https://doi.org/10.1016/S00431354(99)00359-0

Sharpley, A.N. and J.K. Syers 1979. Phosphorus inputs into a stream draining an agricultural catchment, 2: Amounts contributed and relative significance of runoff types. Water, Air and Soil Pollution 11: 417-428. doi: https://doi.org/10.1007/BF00283433

Siriweera, W.I. 1994. A study of the economic history of pre-modern Sri Lanka. Vikas Publishing House, New Delhi. 176 pp. 